\title{
Effect of soaking process on physical properties of mature pepper berries (Piper nigrum L.)
}

\author{
${ }^{1}$ Megat, A.A.P.N., ${ }^{1,2,}{ }^{*}$ Shamsudin, R., ${ }^{3}$ Che Man, H. and ${ }^{1}$ Ya'acob, M.E. \\ ${ }^{1}$ Department of Process and Food Engineering, Engineering Faculty, Universiti Putra Malaysia, 43400 \\ Serdang, Selangor, Malaysia. \\ ${ }^{2}$ Institute of Advanced Technology, Universiti Putra Malaysia, 43400 UPM, Serdang, Selangor, Malaysia. \\ ${ }^{3}$ Department of Biological and Agricultural Engineering, Engineering Faculty, Universiti Putra Malaysia, \\ 43400 Serdang, Malaysia.
}

\begin{abstract}
Article history:
Received: 15 July 2019

October 2019

2019

Available Online: 10

February 2020

\section{Keywords:}

Soaking process,

Physical properties,

Mature,

Pepper berries
\end{abstract}

Received in revised form: 14

Accepted: 22 November

DOI:

https://doi.org/10.26656/fr.2017.4(S1).S04

\begin{abstract}
This study was carried out to determine the effect of the soaking process on the physical properties of the mature pepper berries. The soaking process was conducted by immersing pepper berries in water. The results showed the dimensions of the pepper berries before soaking was $5.24 \mathrm{~mm}$ (minor axis), $5.57 \mathrm{~mm}$ (medium axis) and $5.61 \mathrm{~mm}$ (major axis). The weight of pepper berries increased from day 1 (13.58\%) until day $3(16.92 \%)$ and decreased after day $4(0.77 \%)$ until day 7 of soaking $(13.08 \%)$. The water uptake ratio of soaked pepper berries increased from $1.14 \%$ (day 1) until $1.17 \%$ (day 3 ) and then decreased from $1.01 \%$ (day 4 ) until $0.87 \%$ (day 7 ). The fracture force required to fracture the pericarp was decreased starting from $67.21 \mathrm{~N}$ (day 1) decreased until $21.40 \mathrm{~N}$ (day 7). The colour of mature pepper berries was changed into black-brown colour $(\mathrm{L}=34.16, \mathrm{a}=$ $1.38, \mathrm{~b}=1.40)$.
\end{abstract}

\section{Introduction}

Spices are defined as parts of the plant, either whole or ground that used to flavour, colour, season, preserve and convey the aroma in food (Rosnah and Chan, 2014; Embuscado, 2015). One of the most popular spices in the world is black pepper (Piper nigrum L.), also known as the King of Spices. The pepper belongs to the Piperaceae family. Its plant is a vine that climbs, blooms, and the peppercorn is almost obtained in mature berry of the plant. In Malaysia, mostly the pepper produced in Sarawak (Malaysia's largest pepper production) and Johore. Other than black pepper, there are various types of pepper including white, yellowish, reddish and green. The green pepper berries are immature berries meanwhile, the matured pepper berries are the yellowish or reddish pepper berries. These two types of pepper have the same average diameter, $5 \mathrm{~mm}$ to $6 \mathrm{~mm}$. According to the Malaysian Pepper Board (MPB), there are few recommended pepper varieties such as Kuching, Semonggok Emas and Semonggok Aman. Kuching is the most preferred variety for white pepper production due to its characteristic which it has vigorous growth, higher yielding and its pericarp is thinner when compared to the others. White pepper is a black pepper (Piper nigrum L.) value-added form. Compared to black pepper which has a sharp, pungent aroma and flavour, white pepper has a mild flavour and pungency (Jagella and Grosch, 1999). White pepper is produced by undergoing the soaking process which important step in white pepper production. Retting is a process in white pepper production to enable slackening and fibre separation by involving natural microorganisms to break chemical bonds (Akin, 2010). The natural fibre (pectin) present in the pepper skin's mesocarpic fleshy area begins to enzymatically degrade and break apart from the core during the process (Vinod, Kumar, and Zachariah, 2014). Any of the rettings of the process is a soaking technique that is a process of becoming soft and saturated as the result of being immersed in water or other liquid. The soaking technique will cause the outer skin of pepper berries to become soft and rotten. The current method used in Sarawak to produce white pepper is to soak the fresh pepper berries in running water that is usually rivers for $12-14$ days after harvesting and threshing (Rosnah and Chan, 2014). The processing of fresh pepper berries into white pepper takes nearly a month. There are no many data available on the effect of soaking process on physical properties of white pepper, compare many reporting on other food material such as soybean, rice, cowpea, some types of beans, wheat kernel, chickpea, peanuts, maize and others (Kusota, 1979; Bakshi and Singh, 1980; Hsu, 1983; Singh and Kulshrestha, 1987; Sopade and Obekpa, 1990; 
Sopade et al., 1992; Hung et al.,1993; Taiwo et al., 1997; Abu-Ghannam and McKenna, 1997; Verma and Prasad, 1999; Pan and Tangratanavalee, 2003; Bayram et al., 2004; Yasmin et al., 2008; Fernandes et al., 2010; Lima et al., 2014; Ogunnigbo et al., 2018; Zhu et al., 2019). There is also a previous study that is well documented about the effects on physical properties caused by enzymatic rettings of green pepper berries for white pepper production (Rosnah and Chan, 2014). However, effects of the soaking process on physical properties of mature pepper berries were not previously reported for the processing of white pepper. Next, the common problem occurred was the bad condition of the water that influenced the quality of pepper berries. Physical properties are those properties that can be measured and observed without altering the material composition. Dimensions is an important property to design the soaking system. Weight measurement is an external criterion that mostly used for more valuable foods. Generally, the water uptake or water absorption is affected by the product structure, size, maturity, migration of water through the pericarp layer, condensation of water in the capillary and soaking duration. Colour is one of the important quality characteristics of food (Rhim and Hong, 2011; Wang et al., 2018) and therefore determines its final market prices (Vega-gálvez et al., 2009; Xiao et al., 2017; Yang et al., 2018). In fracture force test, the specimen is either compressed between two parallel plates or a plunger held in a cylinder compresses the sample. In a cell, samples can be tested individually or as bulk (Nixon and Peleg, 1994). Saklar et al. (1999) reported that changes in hazelnut texture are attributed to crispness and crunchiness due to roasting. These changes indicate moisture content and process influence the textural properties of materials. So, the objective of this study was to determine the effects of the soaking process on the physical properties of the mature pepper berries during white pepper production. This research is important to improve the existing retting technique and enhance the quality of white pepper production.

\section{Materials and methods}

\subsection{Sample preparations}

The fresh mature pepper berries from variety Kuching were selected as the samples and obtained at a farm in Johor, Malaysia. The mature pepper berries were threshed by using a machine to remove leaves and spikes. After that, the pepper berries were put in a plastic bag of $7 \mathrm{~kg}$. The mature pepper berries were transported to the laboratory under ambient temperature. The sorting was done manually once the mature pepper berries received which only reddish-orange or light yellowish berries were selected for white pepper production. The sorted mature pepper berries were put in another plastic bag to be stored in the chiller (TD-1600, PROTECH, Malaysia) with $3.5^{\circ} \mathrm{C}$ for overnight. These samples were used for the measurement of physical properties and fracture force analysis.

\subsection{Soaking operation}

The sample pepper berries were weighed for $1 \mathrm{~kg}$. Then, the samples were put in a gunny (jute) bag with a length of $28 \mathrm{~cm}$, a width of $23 \mathrm{~cm}$ and a height of 2.5 $\mathrm{cm}$. For this soaking test, $1 \mathrm{~kg}$ of pepper berries and $6 \mathrm{~L}$ of tap water were placed into a soaking container at room temperature $\left(25-29^{\circ} \mathrm{C}\right)$. The proportion of pepper berries to tap water was 1:6 which followed the ratio used for soybean soaking (Bayram et al., 2004) due to similar some characteristics of pepper berries and soybean. The transparent polypropylene soaking container with a dimension of $39 \mathrm{~cm}$ (length), $25 \mathrm{~cm}$ (width) and $37 \mathrm{~cm}$ (depth) was used and the container was covered during soaking. The soaking process was monitored in 7 days and $10 \mathrm{~g}$ of pepper berries (about 110 pepper berries) were removed every day to determine the properties of pepper berries.

\subsection{Physical and mechanical properties}

\subsubsection{Dimension}

A total of 100 pepper berries of the sample were used. A $0.01 \mathrm{~mm}$ accurate digital vernier calliper (Series 500, Mitutoyo, Japan) has been used to measure pepper berries dimensions (Sirisomboon et al., 2007; Rosnah and Chan, 2014; Terdwongworakul et al., 2009). The sample dimensions were measured as the major axis (a), medium axis (b), minor axis (c) and diameter as shown in Figure 1. The averages of measured dimensions were determined before the soaking.

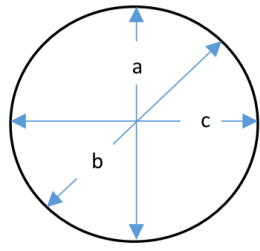

$$
\begin{aligned}
& \text { Dimensions: } \\
& \mathrm{a}-\text { Major axis of berry }(\mathrm{mm}) \\
& \mathrm{b}-\text { Medium axis of berry }(\mathrm{mm}) \\
& \mathrm{c}-\text { Minor axis of berry }(\mathrm{mm})
\end{aligned}
$$

Figure 1. Dimensions of pepper berry

\subsubsection{Weight}

Accuracy of $0.0001 \mathrm{~g}$ of a digital balance (ER-120A, AND, Japan) was used to measure the weight of 100 samples of pepper berries (Rosnah and Chan, 2014) before and after soaking. The average weight of pepper berry was obtained by dividing the total weight of 100 samples with 100 . The replications were done three times for 7 consecutive days.

\subsubsection{Water uptake ratio}

Pepper berries were soaked in tap water. A total of 
100 pepper berries as sample were taken out from the gunny (jute) bag placed in a soaking container. The sample was weighed and calculated by the following equation:

$$
\text { Water uptake }(\%)=\frac{\text { Weight of soaked pepper berries }}{\text { Weight of raw pepper berries }}
$$

The replications were done three times for 7 consecutive days.

\subsubsection{Colour}

Colour measurements of pepper berries were conducted before and after the soaking process. A colour meter (UltraScan Pro, HunterLab, USA) was used to determine the colour values such as L*, $\mathrm{a}^{*}$ and $\mathrm{b}^{*}$. The colour values were measured three times. These values were recorded and used in the calculation to obtain the chroma and hue angle by using the equations below (Mohsenin, 1986; Vega-gálvez et al., 2009; Rhim and Hong, 2011; Rosnah and Chan, 2014; Chahbani et al., 2018). The Commission Internationale de L'Eclairage (CIE) 'Lab' colour space coordinates are expressed as L* represents the degree of light (whiteness or darkness), $\mathrm{a}^{*}$ represents the greenness or redness and $b^{*}$ represents yellowness or blueness.

$$
\text { Chroma, } \mathrm{c}^{*}=\left[\left(\mathrm{a}^{*}\right) 2+\left(\mathrm{b}^{*}\right)^{2}\right]^{1 / 2}
$$

Hue angle, $h^{*}=\tan ^{-1}\left(b^{*} / a^{*}\right)$

The browning index (BI) and total colour change (DE) as the other colour parameters were also determined during the soaking process (Subhashree et al., 2017).

$$
\mathrm{BI}=\frac{[100(\mathrm{x}-0.31)]}{0.17}
$$

Where as

$$
\begin{aligned}
& \mathrm{x}=\frac{(\mathrm{a}+1.75 \mathrm{~L})}{(5.645 \mathrm{~L}+\mathrm{a}-3.012 \mathrm{~b})} \\
& \Delta E=\sqrt{\left(L^{t}-L_{o}\right)^{2}+\left(a^{t}-a_{o}\right)^{2}+\left(b^{t}-b_{o}\right)^{2}}
\end{aligned}
$$

The replications were done three times for 7 consecutive days.

\subsubsection{Fracture force}

Stable Micro System Texture Analyser (TA.XTPlus, Surrey, United Kingdom) with the P/20 cylinder was used to test the fracture force of samples (Rosnah and Chan, 2014). Samples of ten were tested. The pepper berries were placed individually on the plate and compression was applied by using the flat and wide surface of the probe (diameter: $20 \mathrm{~mm}$ ) at a pre-test, post -test and test were adjusted. A load cell and probe speed were set at $0.5 \mathrm{kN}$ (maximum capacity) and $25 \mathrm{~mm}$ per minute (Rosnah and Chan, 2014). The fracture force or fracturability is the first peak of the first compression and considered to textural properties evaluation of soaked mature pepper berries (Kahyaoglu and Kaya, 2006). The replications were done three times for 7 consecutive days.

\subsection{Statistical analysis}

Minitab Statistic 16 Edition was used to analyse the collected data of results. A one-way Analysis of Variance (ANOVA) analysis was performed for all data as a function of time to determine the significant differences between mean values $(P<0.05)$ at $95 \%$ of a confidence level. Tukey tests were carried out to determine the effect of soaking process on physical properties of pepper berries and to predict the homogeneous groups. The triplicate was done for each analysis and the mean of three independent experiments was represented as the data.

\section{Results and discussion}

\subsection{Dimensions}

A total of one hundred mature pepper berries were selected randomly and measurements in determining size of each pepper berry were taken. Table 1 indicates the measurements of dimension on three perpendicular axes such as diameter, major axis, medium axis and minor axis using digital vernier caliper (Series 500, Mitutoyo, Japan). The measurements of dimension were made before soaking process conducted. The average diameter of mature pepper berries was $5.48 \mathrm{~mm}$ with a standard deviation of 0.45 meanwhile the size or diameter of pepper berries was $4 \mathrm{~mm}$ based on the Malaysian Pepper Board (MPB). For the major axis (a), medium axis (b) and minor axis (c), the mature pepper berries have average values of $5.24 \pm 0.47 \mathrm{~mm}, 5.57 \pm 0.53 \mathrm{~mm}$ and $5.61 \pm 0.71 \mathrm{~mm}$. Among the others, the average value of the minor axis is larger and the average value of the medium and major axis is followed. It was found that the average diameter of mature pepper berries is higher compared previous work on green pepper berries (Rosnah and Chan, 2014) and dried black pepper seeds (Murthy and Bhattacharya, 1998) which were $5.21 \mathrm{~mm}$ and $5.12 \mathrm{~mm}$, respectively. These difference in size due to the maturity and varieties used in studies such as Kuching (Rosnah and Chan, 2014) and Malabar (Murthy and Bhattacharya, 1998). Thus, the average diameter of mature pepper berries is higher when compared to previously published works.

Table 1. Average of dimensions of pepper berry before soaking of 100 pepper berries

\begin{tabular}{lcc}
\hline Properties & Average value $(\mathrm{mm})$ & Standard deviation \\
\hline Diameter & 5.48 & 0.45 \\
Major axis, a & 5.24 & 0.47 \\
Medium axis, b & 5.57 & 0.53 \\
Minor axis, c & 5.61 & 0.71 \\
\hline
\end{tabular}


Table 2. Average of weight of pepper berry during 7 days of soaking

\begin{tabular}{|c|c|c|c|c|c|c|c|c|}
\hline \multirow{3}{*}{ Condition } & \multicolumn{8}{|c|}{ Weight $(\mathrm{g})$} \\
\hline & \multirow{2}{*}{$\begin{array}{c}\text { Before } \\
\text { soaking }\end{array}$} & \multicolumn{7}{|c|}{ After soaking } \\
\hline & & Day 1 & Day 2 & Day 3 & Day 4 & Day 5 & Day 6 & Day 7 \\
\hline $1 \mathrm{~kg}$ & $0.13 \pm 0.01^{\mathrm{b}}$ & $0.148 \pm 0.003^{\mathrm{a}}$ & $0.151 \pm 0.002^{\mathrm{a}}$ & $0.152 \pm 0.005^{\mathrm{a}}$ & $0.131 \pm 0.003^{b}$ & $0.119 \pm 0.004^{\mathrm{bc}}$ & $0.115 \pm 0.005^{c}$ & $0.113 \pm 0.004^{\mathrm{c}}$ \\
\hline
\end{tabular}

Different letters indicate statistically significant differences exist $p<0.001$ for each row. Means do not share a letter are significantly different. Tukey test was applied with $95 \%$ simultaneous confidence intervals.

\subsection{Weight}

Weight is calculated by having 100 samples of $1 \mathrm{~kg}$ pepper berries to get an average weight for one pepper berry after dividing by 100 . Statistical analysis was carried out to determine the effect of time on the change of the weight of pepper berries. There was an average weight of pepper berry before and after the soaking process shown in Table 2. The weighted pepper berry was recorded for 7 days of soaking as well. The average weight of pepper berry before soaking was $0.13 \mathrm{~g}$. Meanwhile, the previous work of Rosnah and Chan (2014) shows a green pepper berry weight was $0.11 \mathrm{~g}$ and the weight of Kuching variety pepper berry based on MPB was $0.14 \mathrm{~g}$. This difference shows the greater weight value of the mature pepper berry. After a few days of soaking, the weight of pepper berries was increased steadily at the beginning of the soaking day 1 until the soaking day 3 due to swelling due to the absorption of water under the pericarp "balloon effect". During the process of water uptake, the cell wall enlarges and the pericarp of pepper becomes softened. The weight of soaked pepper berries was increased from day 1 as much as $13.85 \%, 16.15 \%$ on day 2 and $16.92 \%$ on day 3 of soaking in time. According to soybean study (Bayram, Öner, and Kaya, 2004), the increase in weight of pepper berries also is important on deciding dimensions, size and others to design of the soaking system. Then, the subsequent day slowly decreased from day 4 to day 7 of the soaking. The weight of pepper berries increased from $0.13 \pm 0.01 \mathrm{~g}$ (before soaking) to $0.152 \pm 0.002 \mathrm{~g}$ (day 3) and decreased after day 4 $(0.131 \pm 0.003 \mathrm{~g})$ until day 7 of soaking $(0.113 \pm 0.004 \mathrm{~g})$. After the long period of soaking, the pepper skin started to degrade enzymatically and cell structure of the skin would lose. This would cause the weight of soaked pepper berries were decreased slowly starting day 4 as much as $0.77 \%, 8.46 \%$ at day $5,11.54 \%$ at day 6 and $13.08 \%$ at day 7 in time. Time of soaking affected the weight of pepper berry significantly $(P<0.05)$. Thus, these data indicate the changes in the average weight of a pepper berry before and after the days of soaking process. However, there is no standard data for the weight of pepper berry after the soaking process.

\subsection{Water uptake ratio}

To predict suitable absorption conditions, a function of time is one of the characteristics of agricultural products in the evaluation of water absorption. The effect of soaking on pepper berries in terms of water uptake ratio is shown in Table 3. Pepper berries samples were soaked for 7 consecutive days. The water uptake ratio was calculated by using equation 1 . The water uptake ratio of soaked pepper berries was significantly increased with an increasing soaking day $(p<0.001)$ from day 1 (1.14\%) until day $3(1.17 \%)$. However, it was decreased starting at day $4(1.01 \%)$ until day $7(0.87 \%)$. These conditions occur due to pepper berries absorb water quickly at the starting of the soaking process and reduced slowly until saturation is reached. Water uptake by osmosis caused the matrix cells would become weak and the pericarp cells were stretched and swelled during the soaking process of pepper berries. The pepper berries cells become soften and expanded in soaking duration (day), which the migration of water molecules into inner capillaries of pericarp was enhanced (Kashaninejad et al., 2007; Botelho et al., 2013).

Table 3. Water uptake ratio of soaked pepper berries for 7 days

\begin{tabular}{cc}
\hline Soaking day & Water uptake ratio $(\%)$ \\
\hline 1 & $1.14 \pm 0.02^{\mathrm{a}}$ \\
2 & $1.16 \pm 0.02^{\mathrm{a}}$ \\
3 & $1.17 \pm 0.04^{\mathrm{a}}$ \\
4 & $1.01 \pm 0.02^{\mathrm{b}}$ \\
5 & $0.92 \pm 0.04^{\mathrm{c}}$ \\
6 & $0.89 \pm 0.04^{\mathrm{c}}$ \\
7 & $0.87 \pm 0.03^{\mathrm{c}}$ \\
\hline
\end{tabular}

Different letters indicate statistically significant differences exist $p<0.001$ for each column. Means do not share a letter are significantly different. Tukey test was applied with $95 \%$ simultaneous confidence intervals.

\subsection{Colour}

Colour is one of the important parameters to ensure the quality of foods. The colour will change after undergoing any process including the soaking process. This happens because of the reaction between pepper and soaking water. Therefore, the colour of soaked pepper berries is the most important parameter for the acceptability of the final product for white pepper (Bayram et al., 2004). Acceptable soaked pepper berries should not have too dark in colour. The fresh mature pepper berries show colour which ranging from yellowish green $\left(42.05-\mathrm{L}^{*},-36.69-\mathrm{a}^{*}, 40.57-\mathrm{b}^{*}\right)$ to 
red greyish $\left(39.17-\mathrm{L}^{*}, 63.05-\mathrm{a}^{*}, 47.33-\mathrm{b}^{*}\right)$ when referring to CIELAB. It is expressed colour as three values: $L^{*}$ for the lightness of the pepper berries; $a^{*}$ for the redness or greenness of the pepper berries, and $b^{*}$ for the blueness or yellowness of the pepper berries. The different maturity of each fresh pepper berry on a spike is caused the variations of colours. The $\mathrm{L}^{*}$-value for the unsoaked pepper berries was $40.61 \pm 0.62$ and on the day 7 of soaking, its value decreased to $34.16 \pm 1.24$. This decreasing value shows that the samples were turning darker since it is a colour measurement on the light-dark axis. There are some bioactive compound and organic matter such as oleoresins that found in pericarp of pepper berries leached out into the water and also caused the colour changed of pepper berries. The $\mathrm{a}^{*}$-value was decreased during the soaking process from $13.18 \pm 2.27$ to $1.38 \pm 0.53$. According to Bayram et al. (2004), many reactions have been reported to effects the colour during food processing. Pigment degradation, browning reactions and changes in the distribution and structure of the ingredients are among the most common. Change in the colour of the pepper berries can be explained by the combination of the $\mathrm{L}^{*}, \mathrm{a}^{*}$ and $\mathrm{b}^{*}$-values. Browning reaction is very limited occurring during the soaking of the pepper berries, which only showed as decreased in the $\mathrm{L}^{*}$ (lightness) and $\mathrm{a}^{*}$ (redness) values (Table 4 ). Then, the $b^{*}$-value (yellowness) was decreased that affected significantly by soaking time which the $b^{*}$ value for unsoaked pepper berries and the soaked pepper berries were $44.05 \pm 1.02$ and $1.40 \pm 0.50$. These values are in the range of black colour according to CIELAB colour space. Due to enzymatic browning by fermentation and oxidation of phenolic compounds that appear in pepper berries, the yellowish green or red greyish of pepper berries turn into black colour (Amala Dhas and Korikanthimath, 2003; Rosnah and Chan, 2014). The common problem with soaked pepper berries processing is the formation of black and usually, this problem occurs during the soaking process with non-flow water. The average $\mathrm{c}^{*}$ and $\mathrm{h}^{*}$ values of pepper berries before soaking were $44.35 \pm 1.06$ and $73.39 \pm 2.44$ meanwhile, the soaked pepper berries were $2.20 \pm 0.28$ and $45.68 \pm 1.44$. These results are obtained and calculated by substituting the values of $a^{*}$ and $b^{*}$ into the equations. The browning index (BI) shows brown colour purity and can be determined by equation 4 . The average BI of pepper berries before soaking was higher value as much as $269.23 \pm 1.02$ and it decreased to $1.68 \pm 0.31$ on day 7 of soaking. The changes in BI because of the soaked pepper berries were more likely to change the colour to black instead of browning reaction. According to Table 4, the pepper berries can be observed that undergoes colour change after soaking day 7. Total colour change (DE) indicates a change in colour over time and calculated by using equation 6 . The value of total colour change (DE) of soaked pepper berries was $44.73 \pm 0.74$. Thus, all colour values $\left(L^{*}, a^{*}, b^{*}, c^{*}, h^{*}, B I\right.$ and $\left.D E\right)$ have been significantly $(\mathrm{P}<0.05)$ affected by the time of soaking.

\subsection{Fracture force}

Table 4. Colour values of pepper berries before and after soaking process on day 7

\begin{tabular}{ccc}
\hline \multirow{2}{*}{ Properties } & \multicolumn{2}{c}{ Average value of 10 samples } \\
\cline { 2 - 3 } & Before soaking & After soaking day 7 \\
\hline $\mathrm{L}^{*}$ & $40.61 \pm 0.620^{\mathrm{a}}$ & $34.16 \pm 1.24^{\mathrm{b}}$ \\
$\mathrm{a}^{*}$ & $13.18 \pm 2.27^{\mathrm{a}}$ & $1.38 \pm 0.53^{\mathrm{b}}$ \\
$\mathrm{b}^{*}$ & $44.05 \pm 1.02^{\mathrm{a}}$ & $1.40 \pm 0.50^{\mathrm{b}}$ \\
$\mathrm{c}^{*}$ & $44.35 \pm 1.06^{\mathrm{a}}$ & $2.20 \pm 0.28^{\mathrm{b}}$ \\
$\mathrm{h}^{*}$ & $73.39 \pm 2.44^{\mathrm{a}}$ & $45.68 \pm 1.44^{\mathrm{b}}$ \\
\hline
\end{tabular}

Different letters indicate statistically significant differences exist $p<0.05$ for each row. Means do not share a letter are significantly different. Tukey test was applied with 95\% simultaneous confidence intervals.

Fracture force is also known as breaking strength which the stress at which a specimen or sample fails via fracture. Table 5 shows the averages fracture force of soaked pepper berries were 67.21 $\pm 8.40 \mathrm{~N}$ (day 1), $60.39 \pm 5.35 \mathrm{~N}$ (day 2), $53.73 \pm 5.91 \mathrm{~N}$ (day 3), $45.20 \pm 6.52$ $\mathrm{N}$ (day 4), 31.85 $\pm 9.80 \mathrm{~N}$ (day 5), 28.29 $\pm 2.34 \mathrm{~N}$ (day 6) and $21.40 \pm 9.98 \mathrm{~N}$ (day 7), respectively. The result shows that the decrease of fracture force of pepper berries during the soaking process. During the soaking process, the microflora that present in the water and on the surface of pepper berries was producing natural enzymes to degrade and weaken the cell wall structure of pepper berries. Therefore, the fracture force decreased when the soaking time increased and reaching the low value at the end of the process. The soaked pepper berries at day 7 have the lower fracture force compared to the other day. The fracture force for this experiment exhibited to decrease significantly $(P<0.05)$, as the soaking days increased. This is due to the loss of the cell structure and softens enough of pepper skin to be rubbed away. The simple cell separation was occurring due to the breakdown of the middle lamella that contributed to the softening of the pepper berries pericarp. Based on the previously published work (Rosnah and Chan, 2014), the final constant fracture force for the enzymatic experiment at day 9 and non-enzymatic at day 15 soaking days were approximately $20 \mathrm{~N}$. The results obtained were $21.40 \mathrm{~N}$ at day 7 and $20 \mathrm{~N}$ at day 15 (Rosnah and Chan, 2014) are different due to the duration time of the soaking process. According to Rosnah and Chan (2014), the fracture force will reach constant value and pericarp of pepper berries is ready to be rubbed away at fracture force approximately $20 \mathrm{~N}$. Thus, water absorption rates in pepper berries increase, 
shorten the pericarp softening time and low fracture force to break the pericarp.

Table 5. Average of fracture force of pepper berries after soaking process

\begin{tabular}{cc}
\hline Soaking time (day) & Fracture force $(\mathrm{N})$ \\
\hline 1 & $67.21 \pm 8.40^{\mathrm{a}}$ \\
2 & $60.39 \pm 5.35^{\mathrm{ab}}$ \\
3 & $53.73 \pm 5.91^{\mathrm{ab}}$ \\
4 & $45.20 \pm 6.52^{\mathrm{bc}}$ \\
5 & $31.85 \pm 9.80^{\mathrm{cd}}$ \\
6 & $28.29 \pm 2.34^{\mathrm{cd}}$ \\
7 & $21.40 \pm 9.98^{\mathrm{d}}$ \\
\hline
\end{tabular}

Different letters indicate statistically significant differences exist $p<0.05$ for each column. Means do not share a letter are significantly different. Tukey test was applied with $95 \%$ simultaneous confidence intervals.

\section{Conclusion}

The significant changes in the properties of pepper berries start to take place due to the absorption of water during the soaking. These data are providing useful information of this step of pepper berries processing and also for developing new methods for white pepper production in future. The changes in weight (from $0.13 \mathrm{~g}$ to $0.11 \mathrm{~g}$ ), water uptake ratio (from $1.14 \%$ to $0.87 \%$ ), final colour $(\mathrm{L}=34.16 \pm 1.24, \mathrm{a}=1.38 \pm 0.53, \mathrm{~b}=$ $1.40 \pm 0.50)$ and fracture force $(21.40 \mathrm{~N}$ at day 7$)$ of pepper berries during soaking was corresponding to the soaking time. The longer soaking duration resulted in physical properties such as the weight of pepper berry was decreased after soaking due to skin degradation, the changes in water uptake and colour, and the decreasing of fracture force. There is limited data or published work on the physical properties of soaked pepper berries to be compared with. However, the results are considered in a range of acceptability to maintain the quality of white pepper.

\section{Acknowledgement}

The authors express their gratitude to the Universiti Putra Malaysia for providing financial and technical support to conduct this research work.

\section{References}

Abu-Ghannam, N. and McKenna, B. (1997). Hydration kinetics of red kidney beans (Phaseolus vulgaris L.). Journal of Food Science, 62(3), 520-523. https:// doi.org/10.1111/j.1365-2621.1997.tb04420.x

Akin, D.E. (2010). Flax-Structure, Chemistry, Retting and Processing. In Mussig, J. (Ed.) Industrial Applications of Natural Fibres: Structure, Properties and Technical Applications, 87-108. United
Kingdom:

Wiley.

https://

doi.org/10.1002/9780470660324.ch4

Bakshi, A.S. and Singh, R.P. (1980). Kinetics of Water Diffusion and Starch Gelatinization During Rice Parboiling. Journal of Food Science, 45(5), 13871392. https://doi.org/10.1111/j.13652621.1980.tb06561.x

Bayram, M., Öner, M.D. and Kaya, A. (2004). Influence of soaking on the dimensions and colour of soybean for bulgur production. Journal of Food Engineering, 61(3), 331-339. https://doi.org/10.1016/S0260-8774 (03)00137-7

Botelho, F.M., Corrêa, P.C., Martins, M.A., Botelho, S.D. C.C. and de Oliveira, G.H.H. (2013). Effects of the mechanical damage on the water absorption process by corn kernel. Food Science and Technology, 33(2), 282-288. https://doi.org/10.1590/ S0101-20612013005000037

Chahbani, A., Fakhfakh, N., Balti, M. A., Mabrouk, M., El-Hatmi, H., Zouari, N. and Kechaou, N. (2018). Microwave drying effects on drying kinetics, bioactive compounds and antioxidant activity of green peas (Pisum sativum L.). Food Bioscience, 25 (April), 32-38. https://doi.org/10.1016/ j.fbio.2018.07.004

Embuscado, M.E. (2015). Spices and herbs: Natural sources of antioxidants - a mini review. Journal of Functional Foods, 18(Part B), 811-819. https:// doi.org/10.1016/j.jff.2015.03.005

Fernandes, A.C., Nishida, W. and Da Costa Proença, R.P. (2010). Influence of soaking on the nutritional quality of common beans (Phaseolus vulgaris L.) cooked with or without the soaking water: A review. International Journal of Food Science and Technology, 45(11), 2209-2218. https:// doi.org/10.1111/j.1365-2621.2010.02395.x

Jagella, T. and Grosch, W. (1999). Flavour and offflavour compounds of black and white pepper (Piper nigrum L .) I. Evaluation of potent odorants of black pepper by dilution and concentration, European Food Research and Technology, 209(1), 16-21.

Hsu, K.H. (1983). Effect of Temperature on Water Diffusion in Soybean. Journal of Food Science, 48 (4), 1364-1365. https://doi.org/10.1111/j.13652621.1983.tb09236.x

Hung, T.V., Liu, L.H., Black, R.G. and Trewhella, M.A. (1993). Water Absorption in Chickpea (C. arietinum) and Field Pea ( $P$. sativum) Cultivars using the Peleg Model. Journal of Food Science, 58 (4), 848-852. https://doi.org/10.1111/j.13652621.1993.tb09374.x

Kahyaoglu, T. and Kaya, S. (2006). Modeling of 
moisture, color and texture changes in sesame seeds during the conventional roasting. Journal of Food Engineering, 75(2), 167-177. https:// doi.org/10.1016/j.jfoodeng.2005.04.011

Kashaninejad, M., Maghsoudlou, Y., Rafiee, S. and Khomeiri, M. (2007). Study of hydration kinetics and density changes of rice (Tarom Mahali) during hydrothermal processing. Journal of Food Engineering, 79(4), 1383-1390. https:// doi.org/10.1016/j.jfoodeng.2006.04.019

Kusota, K. (1979). Study of the Rate Equation for the Soaking and Cooking of Red Bean. Journal of the Faculty of Applied Biological Science, 18, 161-169.

Lima, F.S.D., Kurozawa, L.E., and Ida, E.I. (2014). The effects of soybean soaking on grain properties and isoflavones loss. LWT - Food Science and Technology, 59(2P2), 1274-1282. https:// doi.org/10.1016/j.lwt.2014.04.032

Mohsenin, N.N. (1986). Physical properties of plant and animal materials. Structure, physical characteristics and mechanical properties. New York: Gordon and Breach Science Publishers.

Murthy, C.T. and Bhattacharya, S. (1998). Moisture dependant physical and uniaxial compression properties of black pepper. Journal of Food Engineering, 37(2), 193-205. https:// doi.org/10.1016/S0260-8774(98)00083-1

Nixon, R., and Peleg, M. (1994). Effect of sample volume on the compressive force-deformation of corn flakes tested in bulk. Journal of Texture Studies, 26(1), 59-69.

Ogunnigbo, C.O., Adetan, D.A. and Olusunmade, O.F. (2018). Effect of soaking time on some engineering properties of cowpea (Vignaunguiculata). Agricultural Engineering International: CIGR Journal, 20(1), 143-149.

Pan, Z. and Tangratanavalee, W. (2003). Characteristics of soybeans as affected by soaking conditions. $L W T$ Food Science and Technology, 36(1), 143-151. https://doi.org/10.1016/S0023-6438(02)00202-5

Rhim, J. and Hong, S. (2011). Effect of Water Activity and Temperature on the Color Change of Red Pepper (Capsicum annuum L.) Powder, 20(1), 215-222. https://doi.org/10.1007/s10068-011-0029-2

Rosnah, S. and Chan, S. (2014). Enzymatic rettings of green pepper berries for white pepper production, 21 (1), 237-245.

Saklar, A.S., Ungan, S. and Katnas S. (2006). Instrumental Crispness and Crunchiness of Roasted Hazelnuts and Correlations with Sensory Assessment. Journal of Food Science, 64(6), 10151019. https://doi.org/10.1111/j.1365- 2621.1999.tb12271.x.

Singh, B.P.N., and Kulshrestha, S.P. (1987). Kinetics of Water Sorption by Soybean and Pigeonpea Grains. Journal of Food Science, 52(6), 1538-1541. https:// doi.org/10.1111/j.1365-2621.1987.tb05874.x

Sirisomboon, P., Pornchaloempong, P. and Romphophak, T. (2007). Physical properties of green soybean: Criteria for sorting. Journal of Food Engineering, 79(1), 18-22. https://doi.org/10.1016/ j.jfoodeng.2006.01.022

Sopade, P.A., Ajisegiri, E.S. and Badau, M.H. (1992). The use of Peleg's equation to model water absorption in some cereal grains during soaking. Journal of Food Engineering, 15(4), 269-283. https://doi.org/10.1016/0260-8774(92)90010-4

Sopade, P.A. and Obekpa, J.A. (1990). Modelling Water Absorption in Soybean, Cowpea and Peanuts at Three Temperatures Using Peleg's Equation. Journal of Food Science, 55(4), 1084-1087. https:// doi.org/10.1111/j.1365-2621.1990.tb01604.x

Subhashree, S.N., Sunoj, S., Xue, J. and Bora, G.C. (2017). Quantification of browning in apples using colour and textural features by image analysis. Food Quality and Safety, 1(3), 221-226. https:// doi.org/10.1093/fqsafe/fyx021

Taiwo, K.A., Akanbi, C. and Ajibola, O.O. (1997). The effects of soaking and cooking time on the cooking properties of two cowpea varieties. Journal of Food Engineering, 33(3-4), 337-346. https:// doi.org/10.1016/s0260-8774(97)87278-0

Terdwongworakul, A., Chaiyapong, S., Jarimopas, B. and Meeklangsaen, W. (2009). Physical properties of fresh young Thai coconut for maturity sorting. Biosystems Engineering, 103(2), 208-216. https:// doi.org/10.1016/j.biosystemseng.2009.03.006

Vega-gálvez, A., Scala, K.D. Rodríguez, K., LemusMondaca, R., Miranda, M., Lopez, J. and Perez-won, M. (2009). Effect of air-drying temperature on physico-chemical properties, antioxidant capacity, colour and total phenolic content of red pepper. Food Chemistry, 117(4), 647-653. https://doi.org/10.1016/ j.foodchem.2009.04.066

Verma, R.C. and Prasad, S. (1999). Kinetics of absorption of water by maize grains. Journal of Food Engineering, 39(4), 395-400. https:// doi.org/10.1016/S0260-8774(99)00027-8

Vinod, V., Kumar, A. and Zachariah, T.J. (2014). Isolation, characterization and identification of pericarp-degrading bacteria for the production of offodour-free white pepper from fresh berries of Piper nigrum L. Journal of Applied Microbiology, 116(4), 890-902. https://doi.org/10.1111/jam.12431 
Wang, J., Law, C., Nema, P.K., Zhao, J., Liu, Z., Deng, L., Gao, Z. and Xiao, H. (2018). Pulsed vacuum drying enhances drying kinetics and quality of lemon slices. Journal of Food Engineering, 224, 129-138. https://doi.org/10.1016/j.jfoodeng.2018.01.002

Xiao, H., Pan, Z., Deng, L., El-mashad, H.M., Yang, X., Mujumdar, A.S., Gao, Z. and Zhang, Q. (2017). Recent developments and trends in thermal blanching - A comprehensive review. Information Processing in Agriculture, 4(2), 101-127. https:// doi.org/10.1016/j.inpa.2017.02.001

Yang, X.H., Deng, L.Z., Mujumdar, A.S., Xiao, H.W., Zhang, Q. and Kan, Z. (2018). Evolution and modeling of colour changes of red pepper (Capsicum annuum L.) during hot air drying. Journal of Food Engineering, 231, 101-108. https://doi.org/10.1016/ j.jfoodeng.2018.03.013

Yasmin, A., Zeb, A., Khalil, A.W., Paracha, G.M.U.D. and Khattak, A.B. (2008). Effect of processing on anti-nutritional factors of red kidney bean (Phaseolus vulgaris) grains. Food and Bioprocess Technology, 1 (4), 415-419. https://doi.org/10.1007/s11947-0080125-3

Zhu, L., Wu, G., Cheng, L., Zhang, H., Wang, L., Qian, H. and Qi, X. (2019). Effect of soaking and cooking on structure formation of cooked rice through thermal properties, dynamic viscoelasticity, and enzyme activity. Food Chemistry, 289, 616-624. https://doi.org/10.1016/j.foodchem.2019.03.082 